\title{
The Inevitable Lightening of Citizenship
}

\begin{abstract}
This paper scrutinizes the paradox of the increasing objective yet diminishing subjective value of citizenship in Western states. The decreasing subjective value points to an inevitable lightening of citizenship, which persists despite states' recent efforts to upgrade and re-nationalize citizenship by ceremony, civic integration tests, and more exclusive rights. I discuss some features of citizenship light, most notably instrumentalism and a dissociation of citizenship from nationhood. The recently court-empowered European Union citizenship serves as an illustration.
\end{abstract}

Keywords: Citizenship; Immigration; Liberalism; Nationalism; Sociology of the State; Europe and the European Union.

T H E C U R R E N T E V O L U T I O N of citizenship poses a paradox. On the one hand, in a world of huge and growing disparities of wealth and security, yet one that is more connected than ever by technology and ideas, the objective value of citizenship (in the right kind of state) must further increase. On the other hand, for the lucky ones in possession of it or close to it, citizenship's subjective value is likely to be low and lower. This paradox is exemplified by two strikingly opposite recent statements on the "worth" and trends of citizenship in the West, Ayelet Shachar's The Birthright Lottery (2009) and Peter Spiro's Beyond Citizenship (2008). Shachar (2009) points to the startling fact that much of the world's riches and life-chances are divided up by the morally arbitrary fact of birth, considering that 97 percent of the world's population are citizens at birth (only three percent being naturalized and thus former immigrants). The near-half of the world's population that is born with the "wrong" citizenships, mostly in the poverty zones of Southeast Asia and Sub-Saharan Africa, has to survive on less than $\$ 2$ a day; children born in the poorest nations are five times more likely to die before the age of five. Is there more need to underline the value of citizenship in the West? At the same time, contrary to the contractual underpinnings of the

Christian Joppke, Université américaine de Paris, [cjoppke@aup.fr].

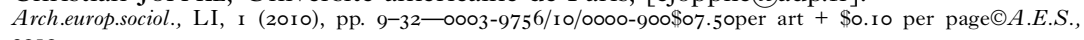
2010 
modern state and the achievement ideology of modern society, citizenship is acquired for most as a "form of inherited property" (Shachar and Hirschl 2007, p. 254). But whereas the morally corrupting and dysfunctional consequences of inheriting material wealth have been amply debated and subsequently curtailed by law (see most recently Beckert 2007), the transmission of political membership still proceeds much like the feudal "fee tail" or "entail" regime for inheriting landed property in medieval England, in which property transfer is untaxed and infinite in duration, land much like citizenship being passed on "from one generation to another in perpetuity" (Shachar and Hirschl 2007, p. 270).

While most scholarship on citizenship has zeroed in on the "gatekeeping" function of citizenship, bickering about the lot of (always few and privileged) immigrants who are thereby included or excluded, the "wealth-preserving" aspect of hereditary citizenship for the vast rest, our naturalized immigrants included, has faded from view - this is, indeed, the "'black hole' of citizenship theory" (Shachar and Hirschl 2007, p. 274). Who would deny that if inherited citizenship, this "striking exception to the modern trend away from ascribed statuses in all other areas"' (Shachar 2009, p. I3), is to prevail, taxing it or requiring human services in terms of a "birthright privilege levy" as a price for their privilege is the minimum that the lucky ones owe those who are born in the wrong places, without any wrongdoing on their part, and without much of a chance of even joining the intrinsically small elite of immigrants. Never has the worth of citizenship and its morally uncomfortable consequences for the privileged half of humankind been more effectively expressed.

Contrast this with Peter Spiro's Beyond Citizenship (2008), which - he submits - should really have been called The End of Citizenship (Spiro 2008, p. 7). As if nothing had happened in the past two decades, both in the real world and in the world of scholarship, it reiterates and applies to the case of the United States the "post-national membership" diagnosis that Yasemin Soysal (I 994) had met for early-i 990 s Europe. Yet there is much going for it, as Spiro rehearses well-known facts that do not thereby become less true. With globalization, the "importance of space and territorial boundaries declines" (Spiro 2008, p. 4), and so does the importance of the one institution defined by space and territory: the state. In a world of increasingly condoned multiple citizenships and strengthened alien rights, citizenship in that diminished institution, the state, must mean less than in the past. The "declining legal significance of the status", in turn, reinforces the 
"waning intensity of bonds among members" (ibid., p. 6). The fact that "over-inclusive" jus soli citizenship in America, which continues to be available even to the children of illegal immigrants or mere transients, has not stirred much debate demonstrates for Spiro the "declining importance of citizenship itself" (ibid., p. 30). As he intriguingly suggests, there is a "feedback loop of diluted ties": "The larger the group of happenstance citizens, the less likely the status will be consequential, which renders existing citizens more accepting of expansive admission criteria and the addition of nominal members, which in turn entrenches the lack of consequence" (ibid., p. 3I). In other words, the larger the radius of citizenship as formal status the less it can mean in terms of rights and identity. ${ }^{\text {I }}$ With respect to rights, citizenship is said to make "very little difference" (ibid., p. 8I ). That is both old, resonating with America's traditionally thin citizenship, and new, as even the mid-I990s onslaught on the welfare rights of immigrants could be revoked piece-by-piece so that, once again, there is "near equality for the purposes of state assistance" (ibid.). Conversely, except for jury duty, there are no specific obligations of citizenship, because taxes and even military service are also imposed or imposable on resident aliens. With respect to identity, "America's dilemma" is that "inclusion dilutes identity" (ibid. p. I 57). Predictably, and more questionably, buying into the hyphenated citizenship scenario of contemporary citizenship studies (Isin and Turner 2002), according to which there is a plethora of (sexual, cultural, urban, global, ecological etc.) citizenships in the plural, Spiro sees "the center of community" shifting to "locations other than the state" (Spiro 2008, p. I37), such as the gated communities and other private bodies that now "regulate our existence" (ibid., p. I48). As the state is downgraded to one of many forms of association, "the significance of membership issues outside of the state will grow in proportion to the importance of nonstate communities" (ibid., p. I 5 I), and membership in all of these other groups is also conceivable in terms of citizenship. So, in lieu of one citizenship there are many citizenships for each one of us, without any single one that might trump all other memberships.

This raises the question: how can citizenship be both "back with a vengeance" (Shachar 2009, p. 2) and in "irreversible" decline (Spiro 2008 , p. I62)? The answer is: it is a matter of perspective, and particularly of factoring in or out host states' immigration policies.

${ }^{1}$ For the distinction between status, rights, and identity as key dimensions of

citizenship as the latter meets the fact of immigration, see JoPPKE (2007). 
Shachar's perspective is mainly that of the losers in the "birthright lottery", which condemns the majority of humanity to poverty, starvation, and early death. For no other group, the majority of mankind, is the objective value of citizenship more apparent. But, in addition, because immigration policy is factored out of the analysis, citizenship law is seen as doing all the cuts. By contrast, Spiro's perspective is above all that of the legal immigrant elite that, having cleared the crucial hurdle of territorial access, may choose between permanent residence and citizenship. The indisputable truth in Spiro's analysis is that the value of an immigrant visa by far surpasses that of formal citizenship. Contrary to the current citizenship rhetoric beloved of politicians of all stripes and countries (see below; also Joppke 2008a), "the real prize is legal residency, not citizenship. It's all about the green card, not the naturalization certificate" (Spiro 2008, p. I 59). Contemporary campaigning for upgrading citizenship may bring about cosmetic change to this reality; it cannot change it at heart. Conversely speaking, only the immigration policy watchdog has allowed citizenship to take on the lightened contours that it indisputably has throughout the West. Only because the vast majority of humankind is locked out from the purview of Western states' citizenship by these states' immigration policies (which by definition are vastly more exclusive than inclusive, even in their most generous variants), could citizenship become more porous at the fringes and could the distinction between citizen and legal resident alien become blurred.

\section{Re-nationalizing citizenship?}

If Spiro's provocative line of citizenship "almost gone begging for customers" (Spiro 2008, p. 9r) did not capture an element of truth, contemporary campaigns for upgrading citizenship, conducted from Europe to Australia, would be meaningless. These campaigns are desperate, yet ultimately futile, rearguard actions against the inevitable lightening of citizenship in the West, that is, against a citizenship that is easy to access, whose rights do not go much beyond the rights that many non-citizens already enjoy, and whose identity is thin and procedural, incapable of sharply setting apart one nation-state society from other such societies.

Britain is a prime example of a state desperately seeking to renationalize a citizenship deemed too light and inconsequential for its 
(prospective) incumbents, which, of course, has a long pedigree in Britain (not unlike America's historically thin citizenship). The current Labour government's strategy has been to "raise the visibility of national citizenship in response to growing anxieties about identity and migration in our more fluid societies" (Goodhart 2006, p. 9). Apart from prescribing symbols and ceremony and the introduction of a standardized citizenship test in 2005, which is little more than catching up with the United States in this domain, there is a novel, hard legal element to this strategy, which is to tie more rights and benefits to formal citizenship than to legal resident status. Concretely, Goodhart advocates a "formal two-tier citizenship", with a "temporary British resident status with fewer rights and duties" and a "more formal, full citizenship" (ibid., p. 44). Goodhart's thrust is to draw a thick line between citizenship and all other statuses, in lieu of drawing it between citizenship and legal permanent residence and all other statuses, as is the legal status quo in Britain and elsewhere in the West. This idea was picked up in 2008 by the Goldsmith Commission that advised the British government on citizenship policy. As its final report bluntly states, "[p]ermanent residency blurs the distinction between citizens and non-citizens. We should expect people who are settled in the UK for the long-term to become citizens" (Goldsmith 2008, p. 6). The British Labour government under Gordon Brown, perhaps wisely so, refused to follow the Goodhart/Goldsmith recommendation to abolish the permanent residence category (and with it Soysalian "postnational membership"), arguing that "it is [not] right to force people to become British citizens should they wish to remain here permanently" (Home Office $2008 \mathrm{~b}$, p. Iо). However, the British government still took some steps toward redrawing the lines between residence and citizenship, first, in excluding temporary residents from all forms of social assistance, and, secondly, in tripling (from one to three years) the duration of the (relatively) rights-deprived limbo period of so-called "probationary citizenship" for those whose aspiration is merely permanent residence and not the acquisition of citizenship (ibid., p. I4).

One wonders: If citizenship in the comfort zone matters more than ever, why this nervous attempt, especially in Europe, to upgrade something the priceless worth of which is beyond doubt? The answer is that the new citizenship talk is to compensate for a significant opening for legal immigration in Europe, highly selective and skillfocused, but deeply unpopular nevertheless. As a result of this opening, the immigration policy watchdog is less available than in 
the past to permit drift on the citizenship front. Moreover, the function of citizenship talk is less to be found in its illocutionary purpose of integrating newcomers than in its perlocutionary effect of pacifying ill-disposed natives. Witness that the transition to what the current British Labor government calls "earned citizenship" is nervously in sync with public preferences, distilled as it is from an unprecedented three-month exercise of "consultation" and "listening meetings" with the public (Home Office 2008a, 2008b). The intellectual blacksmith of New Labour's citizenship policy, David Goodhart, does not hide the fact that his proposals are "defensive measures designed to persuade an anxious public that populists do not in fact have the answers and that British citizenship [...] remains valued and protected by mainstream politics" (Goodhart 2006, p. $55 \mathrm{f}$ ). ${ }^{2}$ It is not by accident that the country that prides itself on having become Europe's biggest immigration magnet is also the country with the most robust, notionally re-nationalized citizenship policy. Conversely, one might argue that the flower of post-nationalism (still best articulated by Soysal I 994) had blossomed in a context of intended zero-immigration, when the rhetorical (never factual) denial of territorial access had taken the drama out of the permanent-residence versus citizenship tango.

In an earlier issue of this journal, I had depicted contemporary citizenship as being in the cross-fire of de- and re-ethnicizing forces, catering to immigrants and emigrants, respectively, both equally galvanized by globalization processes, yet with opposite politicalideological connotations (Joppke 2003). Almost a decade later, with sufficient time for post-200 I Islamic terrorism to have worked out its devious implications for citizenship, the subtly nationalist "reethnicizing" trend has been dwarfed by an open campaign for "re-nationalization", partially revoking a prior (“de-ethnicizing”) liberalization of access to citizenship (particularly through raising the hurdles for naturalization). The new citizenship tests, which are mushrooming from the Netherlands to Australia, are a prime example of this. The rallying cry of interior ministries from The Hague to Canberra is that citizenship is to be more difficult to attain and more highly "prized" than in the past; it is to be the "first prize" as a Dutch Immigration Minister inimitably put it (quoted in Van Oers, de Hart, and Groenendijk 2006, p. 403). This campaign combines

\footnotetext{
2 For a critique of Goodhart and New Labour's strategy of “mollifying Middle England”, see Ратнак (2007, p. 265).
} 
contradictory philosophical elements. On the one side, there is the "neoliberal" emphasis on "responsibilizing" the individual (to put it with David Garland, 200I), holding her responsible for her own successful, officially certified integration without which citizenship would be denied to her, thus unburdening resource-starved states from integrative tasks they no longer can or will fulfill. On the other side, there is a renewed emphasis on cultural assimilation, which had been repudiated under the old reign of "de-ethnicizing" citizenship, though with the new twist that liberalism is the culture that newcomers are to be socialized into. ${ }^{3}$ With an eye on the particularly drastic case of the Netherlands, one author characterized the resulting amalgam as "neoliberal communitarianism" (Schinkel 2009), claiming that it implied a "re-sacralization" of the nation. While this may be the goal of the political elites who talk the citizenship talk, it is immediately undermined by its "neoliberal" component, which subjects citizenship to the rational calculation of individuals. Witness that citizenship as "earned" or as "prized possession" is still a rather utilitarian thing whose measure of worth is what's in it for the individual - how could it ever become the basis for a "re-sacralized" nation?

\section{Into the heart of citizenship light: instrumentalism}

Almost in passing, David Goodhart (2006) concedes a fundamental limit to upgrading or re-nationalizing citizenship in current times. "The modern nation-state", Goodhart (ibid., p. I7) argues, "is based not on a universal liberalism but on a contractual idea of club membership". To the degree that this metaphor holds, citizenship is vitiated by instrumentalism, giving a lie to his principled rhetoric of “progressive nationalism”. Along such lines, one economist recently asked whether citizenship was turning into a "voluntary club membership", analyzable in terms of the theory of club goods (Straubhaar 2003). Like clubs, states provide goods whose consumption is "nonrivaling" among its members yet from which non-members may still be "excluded". To the degree that, in a world of migration, more and more people choose their state, states become "instrumental

\footnotetext{
3 For evidence that applied "political liberalism" is the main content of the new citizenship tests, see Michalowski's (2009)
} instructive comparison of four Western
European countries and the US. 
associations" (Zweckgemeinschaften), like clubs. From this follows, incidentally, a robust admissions policy, according to which the "benefits" for existing members must always exceed the "cost" of accepting new members. Still, extant norms of non-discrimination have to be respected, the two legitimate admissions criteria being a capacity to pay (Zahlungsfähigkeit) and a willingness to accept the club rules (Rechtsbewusstsein). This mirrors the current emphasis on economic self-sufficiency and civic proceduralism in states' revamped naturalization laws.

However, Thomas Straubhaar (2003, p. 87) sees one "decisive difference" between states and clubs: "the state can force its citizens to risk their lives for the protection of the community". This echoes Michael Walzer's (I983, p. 4I) observation that states are not like clubs because state membership is involuntary for most, while club membership is always and inherently voluntary. Identity, we know, is most strongly invested in the non-chosen aspects of human existence, and this is what states have nonchalantly poached on in the high noon of nationalism, when citizenship was not light but indicative of a "community of character" (ibid., p. 62).

However, which state in the West still asks its citizens to "unconditionally subordinate individual interest" to that of the collectivity (Straubhaar 2003, p. 86)? Even America, where nationalism is stronger than elsewhere in the West, no longer asks its native sons to risk their lives on the battlefield - while a good number of poor noncitizen immigrants are doing so each day, in a professional army that provides them with a job and a prospect for life. ${ }^{4}$ Some thirty years ago, Morris Janowitz noticed a "priority on rights versus obligation in the political process of Western political democracies" (Janowitz, I980, p. I), which exposes as empty rhetoric the ritual notion that citizenship rests on a "balance of obligations and rights". As alarmist and fashion-pandering as much of the "decline of citizenship" talk is, an indisputable element of truth is its pointing to a new context of "post-heroic geopolitics", which makes "the role of the patriotic citizen far less crucial to [...] the state" (Falk 2000, p. I3). Most historical expansions of citizenship rights, especially social rights, such as Britain's Beveridge Plan that promised cradle-to-the-grave welfare benefits for everyone, occurred in the aftermath of war, being

\footnotetext{
4 In February 2009, the Pentagon even announced to recruit immigrants with temporary visas (and not just, as before, legal permanent residents), offering them a short-
}

cut to citizenship ("US army "wants more immigrants"', $B B C$ News, I 5 February 2009, http://news.bbc.co.uk). 
compensation for citizens' having put their lives at risk for the collectivity. To the degree that recruitment for battle and participation in war has disappeared as a general citizen obligation in the West, and to the degree that the professional soldier has replaced the citizen soldier, the historical engine of citizenship rights and of strong citizenship identities has irretrievably died, luckily so one must add. ${ }^{5}$

Now that a globalizing economy integrates the West and that the woes of war have become relegated to the Rest, an instrumental attitude to citizenship cannot but grow and grow. If one revisits Rogers Brubaker's classic "ideas and ideals" defining membership in the nation-state (Brubaker I989, pp. 3-6), which were "largely vestigial" by the late I 980 , one must conclude that twenty years later they have become more vestigial still. Of his six "ideas and ideals",6, only the norm that membership should be "democratic" still unambiguously holds, as especially European states have made huge strides toward turning immigrants into citizens. In the past few decades, there has been a thorough liberalization of access to citizenship in Europe, which could only partially be reversed by recent restrictions on naturalization (Joppke 2008b). By contrast, with some exceptions, Western states have largely given up on the idea that state-membership should be "unique" (Brubaker I989, p. 4), and dual citizenship has become increasingly tolerated. With the idea of "uniqueness", indeed, goes that of the "sacredness" of membership, which had echoed the religious origins of nationalism. It is less citizens than professional soldiers that still "die for [the state] if need be" (ibid., p. 4), and this is immediately (and realistically) profaned as "blood for oil". With respect to the idea that membership should be "socially consequential" the post-welfare state has shifted responsibility from the collectivity to the individual (a good overview is Gilbert 2002). As this is a trend that has affected citizens and immigrants alike, one can no longer say that the thinning social privileges of membership "define a status clearly and significantly distinguished from that of nonmembers" (ibid., p. 4). Finally, the front-line of contemporary state campaigns for upgrading citizenship is injecting new life into the notion that state-membership should be "based on nation-membership" (Brubaker I989, p. 4), that is, a "community of language, mores, or belief" (ibid.). But the collective self that

\footnotetext{
5 The relationship between military service and the evolution of citizenship has been in the center of the work of Morris Janowitz, by now largely forgotten (e.g., JANOwitz I978, ch. 6).
} 
is conveyed in these campaigns is thin and procedural more than thick and cultural (see Joppke 2008a).

Instrumentality is even directly inscribed into some of states' immigration and citizenship rules, which provide access in return for (sizeable amounts of) cash. While the "investor visas" of Britain, America, and more recently Germany are widely known, much less is known about the fact that some countries, including Austria, the latter in curious departure from its usual hard-lining in this domain, have moved ahead in offering not just immigrant visas but citizenship for cash. For an investment estimated to exceed $\$ 2.5$ million, one can "buy" Austrian citizenship, without any prior residence, language or even interview requirements, the paperwork being done by a consultancy that offers to "liaise with the various government agencies and ministries, and then prepare and lodge your application" (in the Austrian case, for the hefty fee of $\$ 300$ 000). ${ }^{7}$ Such a passport buys its lucky owner visa-free access to 125 countries and territories in the world. Surely, the fact that such schemes usually operate in secret, along with a denial that it is "just a matter of handing money over and getting citizenship" ${ }^{, 2}$, shows the operation of the norm that citizenship should not be instrumental.

However, what goes under the label of "transnational citizenship", is infested to the core by instrumentalism. That is, after all, why states, from Australia to Mexico, have given in to it in terms of accepting dual nationality, which used to be anathema to most of them as recent as ten or fifteen years ago. Rainer Bauböck (2008) wishes to discipline transnational citizenship by means of a "stakeholder" principle according to which the exercise of full political rights in two or more polities would be limited to those who can prove a "genuine connection" with the respective societies. This would save the essence of citizenship as "equal membership in a self-governing political community” (ibid., p. 7). But politics, while certainly the single most problematic aspect of transnational citizenship, is definitely not the gist of it. Instead, economics and personal advancement are. This is why states, on the sending and receiving ends, have given in to it. With an eye on East Asia's resourceful diasporas on the North American

\footnotetext{
7 "Pledge of allegiance", The Economist ( I February 2007) (downloaded from www.economist.com).

${ }^{8}$ An official at the Austrian Ministry of Economic Affairs, quoted in "Pledge of allegiance", The Economist (op.cit.).
}

9 In Rainer Bauböck's (2007, p. 2395) definition, transnational citizenship refers to "a triangular relationship between individuals and two or more independent states in which these individuals are simultaneously assigned membership status and membership-based rights or obligations". 
West Coast, Aihwa Ong (1999) has dubbed the new phenomenon "flexible citizenship", which refers "to the strategies and effects of mobile managers, technocrats, and professionals seeking to both circumvent and benefit from different nation-state regimes by selecting different sites for investments, work, and family relocation". It sports such colorful figures as "astronauts", shuttling across borders on business, and "parachute kids", who are "dropped off in another country by parents on the trans-Pacific business commute" (ibid., p. I9). Flexible citizenship is an affront to the classic ideals of nationstate membership, but it is condoned and furthered by these very states as an "instrument of flexible accumulation", allowing them "to compete more effectively in the global economy" (ibid., p. I30).

\section{Beyond nationhood: EU citizenship}

Instrumental attitudes toward citizenship are indicative of a dissociation between citizenship and nationhood. This key feature of citizenship light is best illustrated by the new European Union citizenship, which is arguably the most innovative and fast-moving citizenship construct in the world today. If one wants to look into the future of citizenship, this is perhaps where it is to be found. EU citizenship is entirely built around the fact of immigration, or what in Europe is referred to as "free movement". It is Roman to the core, providing rights of free movement within Europe, and giving short shrift to the Greek package of politics, democracy, and duties (for the distinction between "Roman" and "Greek" citizenship strands, see Pockock I995). It is worth while rehashing Euro-lawyer Joseph Weiler's early diatribe against the "Saatchi and Saatchi European citizenship" (Weiler I999, p. 335): "To conceptualize European citizenship around needs (even needs as important as employment) and rights is an end-of-the-millennium version of bread-and-circus politics'. But where in the West (apart from Israel, Weiler's spiritual home) is there more to citizenship than rights and almost no duties; where is it marked by "belongingness and originality"; where does it provide a "shield against existential aloneness" (ibid., p. 338)? Citizenship may have been all the things when tied up with nationhood. But it is no longer - at the level of European nation-states no less so than at European Union level. If the national is "Eros" and the supranational is "civilization" (ibid., p. 347), this distinction rests on a romanticized 
vision of national citizenship, one of "civic responsibility and consequent political attachment" (ibid., p. 333), that may exist in the mind of the political theorist but not in the real world.

Certainly, Weiler's ( I 998) defense of a pluralistic Europe has a long pedigree. From the start, there were two competing visions of Europe, the statist vision of a United States of Europe, analogous to the United States of America, and a supranational vision of an "ever closer union among the peoples of Europe", as expressed in the preamble of the I 957 Treaty of Rome that set up the European Economic Community. Couching the European project in citizenship terms, as occurred with the introduction of a EU citizenship in Article 8 of the I 992 Treaty on European Union (Maastricht Treaty), threatened to give victory to the statal unity vision of Europe, at the cost of its true supranational potential of a Europe of "multiple demoi". The latter - as Weiler formulates with an eye on the continent's dark $20^{\text {th }}$ century history "is about affirming the values of the liberal nation-state by policing the boundaries against abuse” (Weiler I 999, p. 34I). However, what Weiler wishes to see at the European level: "citizenship as a hallmark of differentity" (ibid., p. 329) and a "decoupling [of] nationality from citizenship" (ibid., p. 337), has long occurred at the nation-state level. Establishing such citizenship at European level can only accelerate a train that has long departed. In sum, there are no statist or nationalist dangers in dubbing Euro membership "citizenship", because citizenship as "Eros" is already chimera at state-level.

But what is European Union citizenship? Originally introduced in I 992, what is now Article I7(I) of the EC Treaty stipulates: "Citizenship of the Union is hereby established. Every person holding the nationality of a Member State shall be a citizen of the Union. Citizenship of the Union shall complement and not replace national citizenship". The last sentence was inserted in the I997 Amsterdam Treaty, as a defensive measure by member states, when the European Commission had pushed for a residence-based Euro-citizenship that would include third-state nationals (Europe's “immigrants" proper) (Ferrera 2005, p. I42 f). But this "nay" has no legal meaning, because the peculiarity of the EU if compared with state citizenship is set in stone by the preceding sentence: EU citizenship is not grounded in an own EU nationality law but is secondary to holding the citizenship of a member state. This is not unusual in the history of federal citizenships: before the $14^{\text {th }}$ amendment to the US Constitution in 1868 , and before the I9I3 Imperial Citizenship Law, American and German citizenships, respectively, were both derived from sub-federal state 
memberships. By the same token, the derivative quality of EU citizenship is unlikely to be stable, if one also considers the "vital connecting function which nationality plays in Community law" (O'Leary I993, p. 66) and the notorious tendency of the European Court of Justice to arrogate to itself the definition of such terms.

In this respect mirroring contemporary state citizenships, EU citizenship is essentially about rights - there is a token reference in Article I 7(2) of the EC Treaty that EU citizens "shall be subject to the duties imposed (by this Treaty)", only no duties worth the name can be found in the entire text (not even the duty to pay taxes, which could never in any case be an exclusive citizen duty). Instead, suitably figuring ahead of political rights at local and European (notably, not national) levels that in reality no one cares about ${ }^{10}$ (provided in Article I9), the primary Euro-citizen right is the fabled right of free movement, stipulated in Article i 8( I): "Every citizen of the Union shall have the right to move and reside freely within the territory of the Member States, subject to the limitations and conditions laid down in this 'Treaty and by the measures adopted to give it effect'.

As the right of free movement is one of the four classic Eurofreedoms ${ }^{\text {I I }}$ dating back to the EC's first hour as a "common market", Joseph Weiler ( I996) had originally dismissed its elevation into citizen right as "a cynical exercise in public relations" - no new rights were added to already existing rights. There was ground for this, as the "limitations and conditions" proviso in Article I 8( I) seemingly folded back "citizens" into "workers" or other economic agents, whose moves (and no one else's!) were regulated by the EC Treaty. "Europe", after all, is at heart a functional regime to coordinate the economies of member states, peopled by "factors of production" (Weiler I996), not a territorial state, peopled by citizens. Hence the original polemic against EU citizenship as merely a "market citizenship" (Everson I995). Even a most recent, last-nail-in-the-coffin attack on the "poverty of postnationalism" reiterates the well-known line that EU citizen status is a "derivative status that creates no new rights" (Hansen 2009, p. 6).

This is no longer true. European citizenship is postnational citizenship in its most elaborate form, belatedly vindicating Yasemin

\footnotetext{
Io See Adrian Favell's (2003, p. 20) observation that "European citizenship (as providing political rights, CJ) is not a particularly salient issue to Eurostars",
}

("Eurostars" being EU nationals living and working in other member states).

II The four Euro freedoms are "free movement of goods, persons, services and capital" (EC Treaty, article 3c). 
Soysal's earlier claim in this respect (I994, p. I48). What the past critics of an underwhelming EU citizenship could not know, and what current critics overlook, is the activism by the European Court of Justice that has transformed EU citizenship from a derivative status into a free-standing source of rights. Worthy to be labeled "postnational" if there ever was justification for the term, EU citizenship in its presently expansive form is entirely the product of court rules, with only the thinnest relationship to an identity or a demotic force that might warrant the extensive rights that now accrue to Euro-citizens.

In a string of bold and controversial decisions handed down between 1998 and $2004,{ }^{\text {I2 }}$ the European Court of Justice (ECJ) established two fundamental novelties that member states could not have fathomed when launching their window-dressing EU citizenship in I 992: first, that there is a right to free movement and residence inherent in EU citizenship, regardless of previous EU law that required a variant of economic activity; secondly, that there are, next to formal rights of free movement and residence, substantive social rights that accrue to EU citizens qua citizens, outside prior economic status categories. The battle cry accompanying this stunning rights expansion has been the ECJ dicton, included in its September $200 \mathrm{I}$ landmark judgment on Grzelczyk, that "Union citizenship is destined to be the fundamental status of nationals of the Member States". ${ }^{3}$ This is either a misnomer or a glimpse into the future, as EU law even in its currently expansive form does not apply to the purely internal situations of member states but only to situations where a cross-border component is involved. However, as this limitation entails "reverse discrimination" against domestic citizens, who, for instance, now perversely have lesser family unification rights under national law than border-hopping EU citizens may enjoy in the same country under European law, it is unlikely to be stable. Unless, of course, the ECJ shifts to a lower gear, but this has not been its usual way of proceeding.

If one reads the ECJ rules on EU citizenship from Martinez Sala $(\mathrm{I} 998)^{\mathrm{I}}$, which was the first to base equal access to a member-state's social benefit on EU citizenship status, to Trojani $(2004)^{\mathrm{I}}{ }^{5}$, which effectively allows EU citizens to bootstrap their right of residence by

\footnotetext{
${ }^{2}$ The best available summary is CRAIG and De Burca (2008, ch. 23). See also Wind (2009).

${ }^{13}$ European Court of Justice, Case C-I 84/99, Rudy Grzelczyk v Centre public d'aide sociale d'Ottignies-Louvain-la-Neuve, at paragraph $3 \mathrm{I}$.
}

\footnotetext{
${ }^{14}$ European Court of Justice, Case C-85/96, Maria Martinez Sala v Freistaat Bayern.

15 European Court of Justice, Case C-456/02, Trojani v Centre public d'aide sociale de Bruxelles.
} 
tapping the social assistance schemes of their host states, one can almost hear the cry of pain of member states, "But we never meant it this way". As one of the few Euro-lawyers sympathizing with the lot of member states points out, the European Court of Justice has raided the worker versus non-worker distinction that secondary Community law, in terms of directives and regulations, continues to uphold (Hailbronner 2005). Indeed, among the "limitations" and "conditions" of longer-term cross-border movement and residence by noneconomic actors is their possession of "sufficient resources" and of "sickness insurance". This is to avoid benefit tourism and free movers' becoming an "unreasonable burden" on the welfare systems of host states. ${ }^{\text {I6 }}$ However, ECJ case law has blithely ignored, and thereby effectively destroyed, these restrictions. In Trojani (2004), the court peculiarly endorsed a bootstrapping strategy on the part of EU citizens that is not unlike the benefit tourism outlawed by secondary Community law. As the court argued in this case, of course, there was no right of residence for non-workers who lack "sufficient resources". However, as long as a person was lawfully present in a host member state on some other basis (in this case, Belgian national law), she was still entitled to access non-contributory social assistance under the same conditions as nationals. And recourse to social assistance could "not automatically" lead to the revocation of a residence permit. ${ }^{\text {I } 7}$ Held to observe the principle of "proportionality", member states must not equate "recourse to the social assistance system" with the "lack of sufficient resources" that may trigger expulsion. In other words, by having equal access to social assistance, a Euro-citizen can buy herself out of the "lack of sufficient resources" proviso, so that it is effectively void as an obstacle to benefit tourism. "This seems to be logical”, finds a Euro-lawyer (Verschueren 2007, p. 326). The noninitiated are more inclined to call it twisted reasoning, beloved of lawyers. It is the stuff out of which European citizenship is made.

The activism of the European Court of Justice has made EU citizenship "socially consequential”" of sorts (Brubaker I 989, p. 4), but only to the diminishing degree that the national citizenships still exhibit this quality. In fact, such Europeanization must undermine "strong national rights of social and industrial citizenship", without the compensatory rise of strong "supranational rights" in a Europe

\footnotetext{
${ }^{16}$ Directive 2004/58/EC of 29 April 2004 on the right of citizens of the Union and their family members to move and reside freely
}

within the territory of the Member States,
preamble at paragraph Io.
${ }^{17}$ ECJ decision on Trojani, at paragraph 45 . 
that remains socially vacuous (Streeck I 997; more generally Scharpf I 999). Because, in the absence of strong solidarities at European level, the enthusiasm of nation-states to provide tax-based social benefits from which the rest of Europe cannot be excluded, and that may even be consumable anywhere in Europe, must cool down. Accordingly, when European Union law threatened to make "exportable", and thus usable by return migrants anywhere in Europe, a planned supplementary pension scheme (the so-called Fink Modell) that was meant to assist elderly people in coping with the high cost of living in Germany, the German government rather abandoned the idea, which at first had been supported across the political spectrum (Conant 2004, p. 306).

The main conflict stake in the social expansion of EU citizenship was a new type of non-contributory "mixed benefits", which straddles the boundary between social insurance and social assistance, and whose purpose is to "establish a safety net of last resort for the whole citizenry” (Ferrera 2005, p. I3 I; see also van der Mei 2002, p. 552 f). Examples are a guaranteed minimum income for the elderly poor, the long-term unemployed, the disabled, and other vulnerable categories. The creation of such schemes, need-based, tax-paid and thus an expression of a "'we-ness' that typically bind the members of a national community - and them only" (Ferrera 2005, p. I33), has been the gist of welfare state development during its Golden Age in the ig6os and ig7os. States intended them for their citizenry only. Article 4 of Regulation I408 of I97I, which coordinated the social security schemes of Europe for its "migrant workers", excluded from the ambit of the regulation "social assistance", as which one might think the new welfare policies should be classified. ${ }^{18}$ However, the regulation fails to provide a clear definition of either social assistance or social insurance. So it fell to the European Court of Justice to fill the gap, and the court defined the entire mixed benefit schemes emerging since the r 960 , to the consternation of member states, as "social insurance" rather than "social assistance" and thus subject to inclusion in Regulation I408.

The landmark case is Frilli (1972), in which the ECJ defined a supplementary pension benefit, which Belgian law had reserved to Belgian nationals, as "social security", and thus also accessible to other Europeans - the reason being that it "does not prescribe consideration of each individual case, which is a characteristic of

\footnotetext{
${ }^{18}$ Council Regulation (EC) no I408/7I of I4 June I97I, on the application of social

employed persons and to members of their families moving within the Community.
} security schemes to employed persons, to self- 
assistance, and confers on recipients a legally-defined position giving them the right to a benefit." I9 In sum, to the degree that the new "mixed type" benefits were not charity but a right, for which there was no discretion on the part of the granting state, they qualified as "social security" and all Europeans had to be included in them. In a next step, the ECJ ruled a similar pension supplement in France exportable, so that "French taxpayers were de facto subsidizing some poor elderly people in Italy's Mezzogiorno” (Ferrera 2005, p. 134). Making such benefits exportable renders the policy ad absurdum, because the purpose of mixed type policies is to guarantee a minimum subsistence level that is determined by the cost of living in the host state, which is likely to be higher than the cost of living in the mostly less developed states or regions into which the benefit is carried.

No wonder that European member states responded to the ECJ's creativity on the social rights front by way of "evasion, overrule, and preemption” (Conant 2004, p. 3 I 7). Interestingly, as nationality-based restrictions of the mixed welfare measures became unsupportable under European law, the only defense left for member states was "control over residence" (Ferrera 2005, p. I35). This was accomplished in Council Regulation I247/92 of 30 April I992, which stipulated that "special non-contributory benefits", as explicitly listed for each country in an annex to the I97I social-security regulation, had to be granted only in the territory of residence, and only if strict legal residency requirements were fulfilled (on the complexities of establishing residence, see van der Mei 2002, pp. 564-566).

This is precisely where the European Court of Justice's bold foray on European Union citizenship kicked in, because now states were no longer protected from an all-European claimants' onslaught on their welfare systems by limiting access to them to (however expansively defined) "workers". In Grzelczyk, the Belgian authority denying a "minimix" minimum subsistence allowance to a French student deemed itself protected by the fact that he was not a "worker", and thus subject to the "sufficient resource" proviso that could impossibly be circumvented by tapping the host state's social coffers. ${ }^{20}$ The Belgian and Danish governments submitting opinions in this case reiterated the classic line that citizenship of the Union had "no autonomous content"2r, apart from the rights deriving from the EC Treaty and secondary legislation, and the latter clearly upheld the worker versus non-worker distinction.

\footnotetext{
${ }^{19}$ Judgment of the European Court of Justice of 22 June 1972, Case I-72, Rita Frilli $v$ Belgian State, at paragraph $\mathbf{1} 4$.

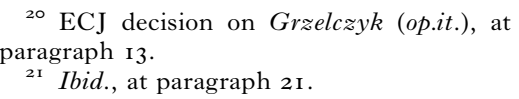


And the French government warned that granting the minimex to a foreign student would "amount to establishing total equality between citizens of the Union established in a Member State and nationals of that State, which would be difficult to reconcile with rights attaching to nationality". ${ }^{22}$ This "total equality" is exactly what the ECJ's Grzelczyk decision accomplished, in famously declaring that "Union citizenship is destined to be the fundamental status of nationals of the Member States, enabling those who find themselves in the same situation to enjoy the same treatment in law irrespective of their nationality."23

As the ECJ haughtily decreed in Grzelczyk, member states had to "[accept] a certain degree of financial solidarity between nationals of a host Member State and nationals of other Member States”, particularly if the difficulties of a Euro citizen were only, as in this case, "temporary". ${ }^{24}$ This astonishing stipulation glosses over the fact that there is a fundamental "tension" between freedom of movement and the "principle of solidarity" (Giubboni 2007). In the demonstrable absence of a genuine Euro-solidarity on the part of governments and their citizens, the "financial solidarity" that is exacted on host states and their tax-paying citizens is not free-standing but parasitic upon the national solidarities that it relies upon but does nothing to refurbish.

If the logic of Europe is to move from a nationality- to a residencebased sense of citizenship, one would think that "immigrants" proper ("third-country nationals" in Euro-jargon) fare well in this. Indeed, contrary to the standard pronouncements in the activist world and by most academics, immigrants have done very well in Europe. This is because it is inherently difficult to justify a distinction between two types of internal free movers, one with and another without a European passport (but with legal permanent residence). There is a stinging sense that both types of free mover should be treated equally. As common as this view is, it is a truly radical view, because it erases the citizen-immigrant distinction. While it may be fed by certain "postnational" developments at member state level (of the kind reported in Soysal's [I994] classic work), above all it shows the power of the denationalizing logic of the European Union. Equality between both types of mover would be achieved if EU citizenship were redefined "as based on residence and not on nationality" (Besson and Utzinger 2007 , p. 58I). While this does correspond to the logic of EU citizenship, it certainly is not at present politically realistic.

22 Ibid., at paragraph 22.

${ }^{23}$ Ibid., at paragraph $3 \mathrm{I}$.

${ }^{24}$ Ibid., at paragraph 44 . 
Even short of this ideal scenario, however, significant progress in binding immigrants into Europe has been made. Those immigrants covered by an association agreement between the EU and their origin country, due to the help of the European Court of Justice, now enjoy "explicit European legal rights" that in many respects approximate, and sometimes even perversely exceed, those of member state nationals (Conant 2004, p. 3 I5). Incidentally, the number of nonEU immigrants protected by an EU association agreement (2,3 million Turks; I million Moroccans; 600 ooo Algerians; and 250000 Tunisians) almost matches the number of EU free movers, which stands at 4,9 million. ${ }^{25}$ A second immigrant group that has achieved near-equality with EU citizens are the family members of EU citizens, which enjoy "quasi-citizenship rights" (Besson and Utzinger 2007, p. I3). And, considering that the r97 I Council Regulation on social security was extended to third-country-nationals in 2003 , one must conclude that "[i]n the employment and welfare areas [...] third country nationals now enjoy virtually the same rights and obligations as nationals" (Ferrera 2005, p. I44).

Of course, the one exception to non-EU immigrants' near-equality with EU citizens is free movement rights, which accrue to EU citizens unconditionally, but to third-country nationals only after five years of legal residence, and then with further strings attached. In this respect, the promise of the 1999 Tampere European Council, which was to grant third country nationals "rights and obligations comparable to those of EU citizens", has not been quite fulfilled. ${ }^{26}$ After the effusive prospect of an EU citizenship based on residence had to be shelved, the emphasis by immigrant advocates indeed shifted toward "approximat(ing)" the legal status of immigrants to that of EU nationals. ${ }^{27}$ The demarche of the European Commission and of the advocacy groups aligned with it became the creation of a "civic citizenship" for immigrants, attributed by virtue of residence rather than nationality.

Judged by the major fruit of the "civic citizenship" campaign, the 2003 Long-Term Residents Directive, ${ }^{28}$ the rights of immigrants trail those of EU citizens in two respects. First, in line with state-level

25 Combined, Europe's two migrant populations that fall within the ambit of EU law are at ca. 9 million, which constitutes slightly under three percent of the total EU population (Conant 2004, p. 3 I 4 f).

${ }_{26}$ Tampere European Council, I 5 and 16 October I999, Presidency Conclusions, at paragraph $\mathbf{I} 8$.
27 Tampere European Council (op.cit.), at paragraph 2 I .

${ }^{28}$ Council Directive 2003/ro9/EC of 25 November 2003, concerning the status of third-country nationals who are long-term residents. 
immigrant rights, the EU-level immigrant rights are highly fragmented and stratified, with students, asylum-seekers, refugees, and temporary workers all excluded from the ambit of the Long-Term Residents Directive. ${ }^{29}$ Secondly, even the status of the most privileged immigrant group, long-term legal labor migrants, remains subject to the logic of "market citizenship" (Everson I995). Article 5 of the Long-Term Residents Directive requires "stable and regular resources" and "sickness insurance" as preconditions for long-term resident status. No such conditions are imposed on EU citizens for acquiring permanent resident status. As Mark Bell (2007, p. 329) astutely observed, "whilst Union citizenship is transiting away from the market citizenship model, this is being reconstructed in respect of third country nationals". A further obstacle not known to EU citizens is making third-country nationals "comply with integration conditions, in accordance with national law" $3^{\circ}$, which enshrines at EU level the civic integration policies toward immigrants now practiced in more and more countries of Europe.

The fact of persistent formal inequality between immigrants and citizens in the European Union is unsurprising - as long as there is an immigration policy at whatever level, national or European, it could not be otherwise. What does surprise is couching the campaign for immigrant rights in the language of (civic) citizenship, and this not by an activist fringe but by the official core of Europe. This shows that European citizenship is "conceptually decoupled from nationality and as a matter of fact from any form of European nationalism” (Besson and Utzinger 2007, p. 576). Whatever there is in terms of a European identity, it is thin and procedural, epitomized by the so-called Copenhagen Criteria that exclude no state from membership as long as it is a market economy, democratic, and respectful of the rule of law, human rights, and the acquis communautaire. ${ }^{3 \mathrm{I}}$ As an imaginative lawyer foresees (Davies 2005, p. 53), in shifting the focus of rights and belonging from nationality to residence, "Europe does not just require the absorption of foreigners, but also the rejection of expatriates". This truly postnational moment has not yet been reached, and perhaps it never will be. But there $i s$ the prospect of "[a] community [...] defined by its current members more than its history, [...]

29 Article 3(2) of the Long-Term Residents Directive (op.cit.).

${ }^{3 \circ}$ Article 5(2) of the Long-Term Residents Directive (op.cit.).

${ }^{31}$ Of course, Article 0 of the Maastricht Treaty stipulates that any "European State" may file an application to join the EU, and not, say, Japan, so that geography and culture cannot be exorcized from the definition of "Europe". 
constantly reinventing itself and changing, belonging to those who participate, not those selected at birth" (ibid., p. 56). This is, indeed, a "model that looks rather American" (ibid., p. 55). It is the prospect that European citizenship holds - a blessing for cosmopolitans, but a curse for whom citizenship should not be light but home (for an intriguing plea for citizenship as "home", see Sacks 2007).

\section{Conclusion}

EU citizenship apparently is implicated with the lightening of citizenship both as dependent and as independent variable, itself exhibiting some of the features of citizenship light, but also reinforcing the lightening of citizenship that is happening independently at member state level. As a citizenship in its own right, EU citizenship used to be ridiculed as a misnomer, but the more interesting optic is to see in it the future of the real thing. Built at the turn of the new millennium, it is a citizenship of our time, entirely free of the baggage of nationhood and nationalism that, however phantom-like, ensnares the citizenships of old. States deem themselves in control because access to European citizenship is still through holding a national citizenship. But this is deceptive. In reality, the court-driven empowerment of European citizenship casts a long shadow over contemporary state campaigns to upgrade the worth of national citizenship. If the British government, as discussed above, seeks to attach more rights to the status of citizenship and in parallel to lessen the attractions of legal permanent residence, this is entirely futile: European Union law commands the inclusion of all EU foreigners and of long-settled immigrants into any upgraded national citizen privileges. In fact, looking back from the European plane at current state attempts to re-nationalize citizenship, the state campaigns are revealed as smoke and mirrors - "symbolic politics" if ever there were any. The future of citizenship is bound to be light, and lighter still with the help of "Europe." Conversely, citizenship could be the opposite of light only at the cost of "Europe", which is what its proponents carefully fail to mention. ${ }^{32}$

So, after Coca Light, "Empire Lite" (Ignatieff 2003), and too many other light things to count, now there is also Citizenship Light. The

\footnotetext{
${ }^{32}$ For a gloomier view of the "return of nationalist integration policies across all of Europe", see Favell (2008).
} 
notion admittedly raises more questions than it can answer. Most importantly, what is its opposite? Obviously, a national citizenship that trumps an individual's other memberships and allegiances. But the moment of such citizenship, in which rights were balanced by obligations but where, in turn, rights were more exclusive to the status of citizen than they are today, was shorter than commonly believed. Above all, it was tied up with a less commendable world of warfare and interstate violence. It is therefore odd that states like Britain, committed like few others to the contemporary world of global trade and peaceful exchange, are nostalgically clinging to a national citizenship that in this case had never even really existed. Note that in modern times citizenship arose together with the idea of human rights, which has always provided its liberal-universalistic core. Most rights listed in the French 1789 Declaration of the Rights of Man and Citizen were human rights, while the first - and still today - quintessential citizen right (in Article 6) was the political right to vote and stand for office. "Citizenship" proper thus is an intrinsically political and collective concept, whose Rousseauian possibilities were more often suppressed by Schmittian realities - at least this has been the experience of Europe's dark $20^{\text {th }}$ century. To the degree that a return to this world is not desired, certainly not by the liberal elites that now prescribe re-nationalized citizenship, the further rise of citizenship light is inevitable indeed, if only because there is no desirable alternative to this.

Bauвöск Rainer, 2007. "Stakeholder Citizenship and Transnational Political Participation", Fordham Law Review, 75, pp. 2393-2447.

-, 2008. "Citizens on the move", Canadian Diversity, 6 (4), pp. 7-I 2.

Beckert Jens, 2007. "The Long Durée of Inheritance Law', European Fournal of Sociology, 48 (I), pp. 79-г 20.

Bell Mark, 2007. "Civic Citizenship and Migrant Integration”, European Public Law, I3 (2), pp. 3 I I -333.

Besson Samantha and Andre Utzinger, 2007. "Introduction: Future Challenges of European Citizenship”, European Law Fournal, I3 (5), pp. 573-590.
Brubaker Rogers, I989. "Introduction" in Brubaker Rogers, ed., Immigration and the Politics of Citizenship in Europe and North America (Lanham, University Press of America).

Conant Lisa, 2004. "Contested Boundaries: Citizens, States, and Supranational Belonging in the European Union", in Migdal Joel, ed., Boundaries and Belonging (New York, Cambridge University Press). Craig Paul and Grainne de Burca, 2008. EC Law, $4^{\text {th }}$ ed. (Oxford, Oxford University Press).

DAvies Gareth, 2005. "Any Place I Hang my Hat", European Law Fournal, I I (I), pp. $43-56$. 


\section{INEVITABLE LIGHTENING OF CITIZENSHIP}

Everson Michelle, i 995. "The Legacy of the Market Citizen", in SHaw Jo and Gillian More, eds., The New Legal Dynamics of European Union (Oxford, Clarendon Press).

FALK Richard, 2000. "The Decline of Citizenship in an Era of Globalization", Citizenship Studies, 4 (I), pp. 5-I 7.

Favell Adrian, 2003. "Games without Frontiers?", typescript (on file with author), subsequently published in European fournal of Sociology, 44 (3).

-, 2008. "Immigration, Migration and Free Movement in the Making of Europe", in Checkel Jeffrey and Peter Katzenstein, eds., European Identity (New York, Cambridge University Press).

Ferrera Maurizio, 2005. The Boundaries of Welfare (Oxford, Oxford University Press).

Garland David, 2001. The Culture of Control (Chicago, University of Chicago Press).

Gilbert Neil, 2002. Transformation of the Welfare State (New York, Oxford University Press).

Giubboni Stefano, 2007. "Free Movement of Persons and European Solidarity", European Law Fournal, I3 (3), pp. 360-379.

Goldsmith Lord, 2008. Citizenship: Our Common Bond (London, HM Printing Office).

Goodhart David, 2006. Progressive Nationalism: Citizenship and the Left (London, Demos).

Hailbronner Kay, 2005. "Union Citizenship and Access to Social Benefits", Common Market Law Review, 42, pp. I245-1267.

Hansen Randall, 2009. "The Poverty of Postnationalism", Theory and Society, 38 (I), pp. I-24.

Home Office, (UK), 2008a. The Path to Citizenship: Next Steps in Reforming the Immigration System, February (London, HM Printing Office).

Home Office, (UK), 2008b. The Path to Citizenship: Government Response to Consultation, July (London, HM Printing Office).

IgnatiefF Michael, 2003. Empire Lite (Harmondsworth, Penguin).

Isin Engin and Bryan Turner, eds., 2002. Handbook of Citizenship Studies (London, Sage).

JANOwitz Morris, I978. The Last HalfCentury (Chicago, University of Chicago Press).

-, 1980. "Observations on the Sociology of Citizenship”, Social Forces 59 (I), pp. I-24.
Joppke Christian, 2003. "Citizenship between De- and Re-Ethnicization”, Archives européennes de sociologie, 44 (3), pp. 429-458.

-, 2007. "Transformation of Citizenship: Status, Rights, Identity", Citizenship Studies I I (I), pp. 37-48.

-, 2008a. "Immigration and the Identity of Citizenship”, Citizenship Studies, I2 (6), pp. 533-546.

—, 2008b. "Comparative Citizenship: A Restrictive Turn in Europe?" Fournal of Law and Ethics of Human Rights, 2, pp. I-4I.

Michalowski Ines, 2009. Citizenship Tests in Five Countries - An Expression of Political Liberalism?, Discussion paper (SP IV 2009-702), Wissenschaftszentrum Berlin.

O'Leary Siofra, i 993. The Evolving Concept of Community Citizenship, Doctoral dissertation, Department of Law, European University Institute, Florence.

Ong Aihwa, I999. Flexible Citizenship (Durham, Duke University Press).

Pathak Pathik, 2007. "The Trouble with David Goodhart's Britain", The Political Quarterly, 78 (2), pp. 26I-27I.

Роскоск J.G.A. I995. "The Idea of Citizenship since Classical Times", in BeIner Ronald S., ed., Theorizing Citizenship (Albany, New York, State University of New York Press).

Sacks Jonathan, 2007. The Home We Build Together (London, Continuum).

Scharpf Fritz, I999. Governing in Europe (Oxford, Oxford University Press).

Schinkel Willem, 2009. The Double Helix of Cultural Assimilationism and Neoliberalism: Interpreting Recent Transformations of the Concept of Citizenship in the Netherlands, typescript.

Shachar Ayelet, 2009. The Birthright Lottery (Cambridge, Harvard University Press).

Shachar Ayelet and Ran Hirschl, 2007. "Citizenship as Inherited Property”, Political Theory, 35 (3), pp. 253287.

Soysal Yasemin, 1994. Limits of Citizenship (Chicago, University of Chicago Press).

Spiro Peter J., 2008. Beyond Citizenship (Princeton, Princeton University Press).

Straubhaar Thomas, 2003. "Wird die Staatsangehörigkeit $\mathrm{zu}$ einer Klubmitgliedschaft?", Leviathan (special edition) 22, pp. 76-89.

Streeck Wolfgang. I997. Citizenship under Regime Competition (Oslo, ARENA working papers, 6). 


\section{CHRISTIAN JOPPKE}

VAn der Mei Anne Pieter, 2002. "Regulation I 408/7I and Co-Ordination of Special Non-Contributory Benefit Schemes", European Law Review, 27 (October), pp. $55^{\mathrm{I}-566 .}$

Van Oers Ricky, Betty De Hart and Kees Groenendijk, 2006. "The Netherlands", in BauböcK Rainer, Eva Ersbøll, Kees Groenendijk and Harald Waldrauch, eds. Acquisition and Loss of Nationality, vol. 2 Country Analyses (Amsterdam, Amsterdam University Press).

Verschueren Herwig, 2007. "European (Internal) Migration Law as an Instrument

\section{Résumé}

Montée de la valeur objective de la citoyenneté dans les pays occidentaux et diminution de sa valeur subjective font paradoxe. Les États ont beau faire des efforts pour donner de la solennité à l'octroi de la citoyenneté (cérémonie de naturalisation et test d'intégration), la conclusion s'impose : la citoyenneté s'allège inévitablement. L'article analyse certains aspects de ce processus, en particulier l'instrumentalisme et la dissociation entre nationalité et citoyenneté. Le débat juridique sur la citoyenneté européenne sert d'illustration.

Mots clés : Citoyenneté ; Immigration ; Libéralisme ; Nationalisme ; Sociologie de l'Etat ; Europe et Union européenne. for Defining the Boundaries of National Solidarity Systems", European Fournal of Migration and Law, 9, pp. 307-346.

WALzer Michael, i 983 . Spheres of Fustice (New York, Basic Books).

WeILer Joseph, r996. The Selling of Europe (NYU School of Law, Jean-Monnet Center, Working paper 96, non-paginated). -, I999. The Constitution of Europe (New York, Cambridge University Press). WIND Marlene, 2009. "Post-national citizenship in Europe: The EU as a 'Welfare rights generator'?" Columbia Fournal of European Law, I 5 (2).

\section{Zusammenfassung}

Das Paradox eines objektiv steigenden aber gleichzeitig subjektiv sinkenden Werts der Staatsbürgerschaft in westlichen Staaten verdient eine genauere Untersuchung. Ihr subjektiv abnehmender Wert weist auf ein unausweichliches "Leichterwerden" der Staatsbürgerschaft hin, trotz gegenläufiger staatlicher Initiativen, den Staatsbürgerstatus aufzuwerten und zu re-nationalisieren (zum Beispiel durch symbolische Verleihungen, Einbürgerungstests und exklusivere Rechte). Ich skizziere einige Elemente der "leichten" Staatsbürgerschaft, insbesondere Instrumentalismus und eine Trennung von Staatsangehörigkeit und Nationalität. Die durch Entscheidungen des Europäischen Gerichtshofs mächtig vorangetriebene Unionsbürgerschaft dient als Illustration.

Schlagwörter: Staatsbürgerschaft; Einwanderung; Liberalismus; Nationalismus; Staatssoziologie; Europa und die europäische Union. 